\title{
Senam bugar lansia berpengaruh terhadap daya tahan jantung paru, status gizi, dan tekanan darah ${ }^{1}$ \\ Sri Thristyaningsih², Probosuseno ${ }^{3}$, Herni Astuti ${ }^{4}$
}

\begin{abstract}
Background: Aging that happens naturally in human life does not only cause physical dysfunction but also have an impact to mental and social aspects. In the elderly there is a problem of degenerative disease. Hypertension has become a serious health problem and a major challenge of public health worldwide because of either high prevalence or major risk factor for cardiovascular disease. Pharmacological as well as non pharmacological efforts have been made to prevent and cure the disease, however until today the growing number of hypertensive patients has not been successfully controlled. Consequently behavioral intervention has to be made to cure hypertensive patients. One of the recommended interventions is fitness exercise for the elderly.

Objective: The study aimed to identify the effect of fitness exercise to increasing stamina of heart and lung, nutrition status and reduced blood pressure of hypertensive elderly at integrated service post of Subdistrict of Pahandut, Palangkaraya Municipality.

Method: The study was a experiment (before and after) without control group using one group pre test post test study design. Subject of the study was a group with pre experimental, evaluation, effect of variables and post experimental evaluation. Measurement was made in week two, three and four to blood pressure, heart and lung stamina, nutrition status of hypertensive elderly, discipline in exercise and food recall 24 hours. The interventions made were lecture and fitness exercise package $D$ for the elderly.

Results: There was significant association between elderly fitness exercise and systolic blood pressure, heart and lung stamina and nutrition status of hypertensive elderly $(p<0.05)$. Result of Wilcoxon signed ranks test and paired sample test between gymnastic elderly on increase of endure capacity heart lung are significantly associated $(p=0,001)$ and so on nutritional status $(p=0,002)$ and decrease sistolik tension $(p=0,001)$ and diastolic tension $(p=0,002)$.

Conclusion: There was significant association between elderly fitness exercise and the increase of heart and lung stamina, nutrition status and the decrease of blood pressure in hypertensive elderly.
\end{abstract}

KEY WORDS elderly fitness exercise, stamina, heart and lung, nutrition status, blood pressure, elderly.

\section{PENDAHULUAN}

Biro Pusat Statistik (BPS) menggambarkan bahwa antara tahun 2005-2010 jumlah penduduk lanjut usia sekitar 19 juta jiwa atau $8,5 \%$ dari seluruh jumlah penduduk. World Health Organization (WHO) memperhitungkan pada tahun 2025, Indonesia akan mengalami peningkatan jumlah warga lansia sebesar $41,4 \%$ yang merupakan sebuah peningkatan tertinggi di dunia (1).

Undang-undang 23 tahun 1992 tentang kesehatan, pasal 19 menetapkan bahwa kesehatan lanjut usia tetap terpelihara dan ditingkatkan agar tetap produktif, serta pemerintah membantu penyelenggaraan upaya kesehatan lanjut usia untuk meningkatkan kualitas hidupnya secara optimal. Berbagai upaya dilaksanakan untuk mewujudkan masa tua yang sehat, bahagia, berdaya guna, dan produktif, di antaranya dengan cakupan, keterjangkauan, dan mutu pelayanan kesehatan untuk penduduk lanjut usia (2).

Sepanjang kehidupan, nutrisi merupakan penentu yang sangat penting terhadap kesehatan, fungsi fisik dan kognitif, vitalitas, kualitas hidup keseluruhan, dan panjang usia. Status gizi menjadi dampak utama timbulnya penyakit pada lanjut usia. Pada saat yang sama, perubahan sosial dan demografi menempatkan lanjut usia pada risiko ketidakamanan makanan dan kurang gizi. Selain kurang gizi, obesitas dan defisiensi mikronutrien juga kerap terjadi pada populasi lanjut usia yang kemudian akan mencetuskan berbagai penyakit kronik (3). Hasil penelitian pada lansia di Bengkulu menunjukkan bahwa berdasarkan analisis multivariat, secara umum status gizi tidak berpengaruh terhadap kejadian hipertensi esensial, tetapi status gizi obesitas mempunyai pengaruh yang bermakna terhadap hipertensi esensial di mana status gizi obesitas mempunyai risiko 4,57 kali $(95 \% \mathrm{Cl}: 1,497-13,958)$ untuk menderita hipertensi esensial dibanding lansia dengan status gizi kurang atau normal setelah dikontrol faktor lain (4).

Berdasarkan pola penyakit rawat jalan di Puskesmas tahun 2006, penyakit pada sistem otot dan jaringan pengikat (penyakit tulang, radang sendi) dan penyakit

\footnotetext{
1 Dipresentasikan pada International Dietetic Update pada tanggal 1517 Oktober 2009 di Yogyakarta kerjasama dengan Asosiasi Dietesien Indonesia, Jurnal Gizi Klinik Indonesia, dan Prodi Gizi Kesehatan FKUGM serta didanai oleh Pendidikan Tinggi Kementerian Pendidikan Nasional.

2 Dinas Kesehatan Kota Palangka Raya, Jl Tjilik Riwut Km 5,5 Palangka Raya 73112, e-mail: thris doni@yahoo.co.id

${ }^{3}$ Bagian Penyakit Dalam Fakultas Kedokteran UGM, JI. Farmako, Sekip Utara Yogyakarta 55281

${ }^{4}$ Instalasi Gizi RSUP Dr. Sardjito, JI. Kesehatan, Yogyakarta 55281
} 
tekanan darah tinggi merupakan penyakit yang banyak diderita pada kelompok usia lebih dari 60 tahun (5). Demikian pula pada penelitian yang dilakukan di RSUD Provinsi Sulawesi Tenggara, yang menyatakan bahwa pasien hipertensi rawat jalan terbanyak berada pada kelompok umur lebih dari atau sama dengan 50 tahun yang terdistribusi sebanyak $60 \%$ pada kelompok intervensi dan $80 \%$ pada kelompok kontrol. Hasil penelitian tersebut menunjukkan sebagian besar subjek (88\%) pada kelompok intervensi yang mendapat konseling dan leaflet pada akhir penelitian diketahui memiliki tekanan darah normal, namun pada kelompok kontrol sebagian besar subjek $(60 \%)$ ditemukan masih menderita hipertensi ringan (6). Hipertensi telah menjadi tantangan dan masalah yang serius bagi kesehatan masyarakat di dunia, tidak hanya karena tingginya prevalensi tetapi juga faktor risiko utama penyakit kardiovaskuler dan penyakit ginjal. Prevalensi hipertensi meningkat sesuai dengan bertambahnya umur dan lebih dari $70 \%$ di antara laki-laki yang berumur 65 tahun menderita hipertensi (7).

Tujuan olahraga atau senam hipertensi adalah bagian dari usaha untuk mengurangi berat badan dan mengelola stres, dua faktor yang mempertinggi risiko hipertensi. Manfaat olahraga teratur terbukti dapat menurunkan tekanan darah, mengurangi risiko terhadap stroke, serangan jantung, gagal ginjal, gagal jantung, dan penyakit pembuluh darah lainnya. Selain itu olahraga dinilai cukup murah dan efek sampingnya kecil bila dilakukan sesuai aturan (8).

Hasil penelitian di Padang pada atlet sepak bola, menunjukkan bahwa variabel persentase lemak tubuh merupakan variabel yang paling berpengaruh terhadap daya tahan jantung paru jika dibandingkan dengan variabel yang lain $(\mathrm{OR}=12)$. Meningkatnya persentase lemak tubuh dapat mengganggu kebebasan seseorang untuk bergerak atau melakukan aktivitas fisik. Penurunan aktivitas fisik ini dapat menurunkan kinerja sistem jantung, paru-paru, fungsi pembuluh darah, dan daya tahan kardiovaskuler yang merupakan gambaran daya tahan jantung paru (9).

Mengingat pentingnya meningkatkan daya tahan jantung paru, mengelola status gizi ideal, dan mengelola tekanan darah pada lansia hipertensi, maka perlu dilakukan penelitian untuk menganalisis pengaruh aktivitas fisik, salah satunya senam bugar lansia. Meskipun selama ini senam bugar lansia sudah menjadi kegiatan rutin yang dilaksanakan di posyandu lansia di Kecamatan Pahandut Kota Palangkaraya, namun belum pernah dilakukan penelitian mengenai pengaruh aktivitas fisik dengan hipertensi pada lansia. Sehingga perlu dilakukan penelitian ini untuk mengetahui pengaruh senam bugar lansia terhadap peningkatan daya tahan jantung paru, status gizi, dan penurunan tekanan darah lansia hipertensi.

\section{BAHAN DAN METODE}

Jenis penelitian adalah experiment (before after) tanpa kelompok kontrol dengan rancangan penelitian one group pretest posttest design. Eksperimen dengan memberikan perlakuan senam bugar lansia (SBL), penilaian dilakukan 1 kali sebelum perlakuan dan 3 kali setelah perlakuan yaitu minggu kedua, ketiga, dan keempat.

Populasinya adalah semua lansia di posyandu Kecamatan Pahandut Kota Palangka Raya. Jumlah sampel yang diteliti sebanyak 74 orang. Besar sampel dihitung berdasarkan rumus besar sampel untuk satu populasi (10) dengan tingkat kepercayaan (Za) sebesar 95\%, proporsi sebesar $25 \%$ yaitu prevalensi masalah gizi lanjut usia berdasarkan data Dinkes 2006 (11), dan presisi (d) sebesar $10 \%$. Sehingga besar sampel minimal adalah 74 orang ditambah $10 \%$ menjadi 81 orang untuk cadangan jika terjadi drop out.

Pengambilan sampel dalam penelitian ini dilakukan secara purposive yaitu diambil semua lansia hipertensi yang sebelumnya dilakukan seleksi sesuai dengan kriteria inklusi, sehingga diperoleh jumlah sampel minimal yang diperlukan. Kriteria inklusi yaitu: bersedia menjadi subjek penelitian, umur 60-69 tahun, lansia dengan penyakit hipertensi primer (esensial) stadium 1 (hipertensi ringan, 140-159 mmHg/ 90-99 mmHg). Sedangkan kriteria eksklusi yaitu: frekuensi senam kurang dari 3 kali per minggu dan durasi kurang dari 30 menit, mempunyai penyakit paru-paru atau jantung.

Variabel penelitian meliputi: variabel independen (senam bugar lansia), variabel dependen (daya tahan jantung paru, status gizi, dan tekanan darah), variabel pengganggu (menghentikan merokok, membatasi asupan natrium, cukup asupan kalium, cukup asupan kalsium, tinggi asupan magnesium, dan asupan lemak terbatas).

Data asupan natrium, kalium, kalsium, magnesium, dan lemak yang dikonsumsi subjek setiap hari diperoleh berdasarkan pengumpulan data dengan metode food recall 3 x 24 jam tidak berturut-turut kemudian dihitung menggunakan program nutri survey. Recall dilakukan oleh enumerator yaitu satu orang lulusan DIII Gizi. Latihan pengisian form food recall 3 x 24 jam dilakukan untuk menyamakan persepsi antara peneliti dengan enumerator.

Kategori asupan natrium (12) yaitu dikatakan lebih jika asupan lebih dari atau sama dengan 1500 mg dan kurang jika asupan kurang dari 1500 mg. Kategori asupan kalium (13) yaitu dikatakan lebih jika asupan lebih dari atau sama dengan 2000 mg dan kurang jika asupan kurang dari 2000 mg. Kategori asupan kalsium (13) yaitu dikatakan lebih jika asupan lebih dari atau sama dengan $800 \mathrm{mg}$ dan kurang jika asupan kurang dari 800 mg. Kategori asupan magnesium (14) yaitu dikatakan lebih jika asupan lebih dari atau sama dengan 300 mg dan kurang jika asupan kurang dari $300 \mathrm{mg}$. Asupan lemak adalah proporsi lemak terhadap angka kecukupan energi berdasarkan jumlah 
energi $2.250 \mathrm{kkal} /$ hari untuk laki-laki dan $1.750 \mathrm{kkal} / \mathrm{hari}$ untuk wanita yang dikonsumsi responden setiap hari, dengan kategori lebih jika lebih dari atau sama dengan $30 \%$ dan kurang jika kurang dari 30\% (15).

Perlakuan senam bugar lansia dilakukan 3 kali seminggu pada 2 Puskesmas yaitu Puskesmas Panarung (terdiri dari 3 posyandu yaitu Posyandu Balinga, Posyandu Mawar, Posyandu Mahaga) dan Puskemas Pahandut (Posyandu Bajenta). Perlakuan yaitu berupa senam bugar lansia disertai ceramah pada minggu kedua dan senam saja pada minggu ketiga dan keempat. Ceramah gizi dengan topik pengaturan makan pada hipertensi diberikan oleh peneliti dan satu orang tenaga S1 Gizi. Materi ceramah merupakan modifikasi dengan diit Dash yang berisi pengertian hipertensi, gejala-gejala hipertensi, faktor risiko hipertensi, tujuan diit, prinsip diit, makanan yang dianjurkan, dan makanan yang dihindari. Perlakuan senam bugar lansia seri D karena senam tersebut untuk lanjut usia (umur 60-69 tahun) kondisi prima. Senam bugar lansia paket D dipandu oleh instruktur senam yang sudah terlatih, dilakukan selama 30 menit dengan tahapan 5 menit latihan pemanasan, 20 menit gerakan peralihan, dan 5 menit gerakan pendinginan dengan frekuensi 3 kali setiap minggu. Senam bugar lansia diadopsi dari persatuan olahraga wanita seluruh Indonesia (PERWOSI) Provinsi Daerah Istimewa Yogyakarta (16).

Jenis data yang dikumpulkan yaitu jenis kelamin, umur, status merokok, asupan natrium, kalium, kalsium, magnesium, dan lemak, daya tahan jantung paru, status gizi, dan tekanan darah. Status gizi lansia diukur berdasarkan body mass armspan (BMA), yaitu perhitungan dari pengukuran berat badan $(\mathrm{kg})$ dibagi rentang lengan $\left(\mathrm{m}^{2}\right)$. Perhitungan daya tahan jantung paru dengan cara jalan kaki selama 12 menit pada lintasan datar dengan jarak tempuh telah diukur terlebih dahulu (dari start $=0 \mathrm{~km}$ sampai finish $=2,4 \mathrm{~km}$ ), kemudian jarak yang dicapai $(\mathrm{km})$ dibandingkan dengan tabel standar sesuai dengan usia dan jenis kelamin. Observasi perlakuan dibantu oleh enumerator. Pengukuran tekanan darah dilakukan dalam posisi duduk pada lengan kanan setelah istirahat selama 5 menit, menggunakan alat sphygmomanometer air raksa $(\mathrm{mmHg})$. Pengukuran dilakukan sebanyak 2 kali dengan jarak waktu kedua pengukuran kira-kira 3 menit, hasil pengukuran tekanan darah sistolik dan diastolik diambil dari pengukuran kedua. Pengukuran tekanan darah dilakukan oleh satu orang perawat yang telah terlatih.

Pengolahan data meliputi pemberian kode dan tabulasi data. Analisis untuk mengetahui pengaruh perlakuan terhadap daya tahan jantung paru, status gizi, dan tekanan darah dengan paired sampel t-test dan wilcoxon signed ranks test dengan taraf signifikan 0,05. Untuk mengetahui hubungan karakteristik subjek dengan penurunan tekanan darah menggunakan uji chi square. Analisis multivariat digunakan untuk melihat variabel independen yang dominan berhubungan dengan variabel dependen menggunakan uji regresi logistik ganda.

\section{HASIL}

\section{Karakteristik subjek penelitian}

Karakteristik subjek menurut jenis kelamin menunjukkan lebih banyak lansia perempuan sebanyak 58 orang (78,4\%) dibanding lansia laki-laki sebanyak 16 orang $(21,6 \%)$. Berdasarkan umur subjek paling banyak berumur 65-69 tahun $(51,35 \%)$. Subjek yang merokok sebanyak 5 orang $(6,8 \%)$ dan yang obesitas 11 orang (14,87\%). Asupan natrium lebih dari atau sama dengan 1500 mg sebanyak 18 orang $(24,3 \%)$, asupan kalium lebih dari atau sama dengan 2000 mg sebanyak 6 orang $(8,1 \%)$, asupan kalsium lebih dari atau sama dengan $800 \mathrm{mg}$ sebanyak 2 orang (2,7\%), asupan magnesium lebih dari atau sama dengan 300 mg sebanyak 3 orang $(4,1 \%)$, dan asupan lemak lebih dari atau sama dengan $30 \mathrm{mg}$ sebanyak 3 orang $(4,1 \%)$.

Tabel 1. Karakteristik lanjut usia (lansia)

\begin{tabular}{|c|c|c|}
\hline Karakteristik & Jumlah & Persentase (\%) \\
\hline \multicolumn{3}{|l|}{ Umur (tahun) } \\
\hline $60-64$ & 36 & 48,64 \\
\hline $65-69$ & 38 & 51,35 \\
\hline \multicolumn{3}{|l|}{ Jenis kelamin } \\
\hline Laki-laki & 16 & 21,6 \\
\hline Perempuan & 58 & 78,4 \\
\hline \multicolumn{3}{|l|}{ Status merokok } \\
\hline Tidak merokok & 69 & 93,2 \\
\hline Merokok & 5 & 6,8 \\
\hline \multicolumn{3}{|l|}{ Status obesitas } \\
\hline Tidak obesitas & 63 & 85,13 \\
\hline Obesitas & 11 & 14,87 \\
\hline \multicolumn{3}{|l|}{ Asupan natrium } \\
\hline Kurang $(<1500 \mathrm{mg})$ & 56 & 75,7 \\
\hline Lebih $(\geq 1500 \mathrm{mg})$ & 18 & 24,3 \\
\hline \multicolumn{3}{|l|}{ Asupan kalium } \\
\hline Kurang $(<2000 \mathrm{mg})$ & 68 & 91,9 \\
\hline Lebih $(\geq 2000 \mathrm{mg})$ & 6 & 8,1 \\
\hline \multicolumn{3}{|l|}{ Asupan kalsium } \\
\hline Kurang (<800 mg) & 72 & 97,3 \\
\hline Lebih $(\geq 800 \mathrm{mg})$ & 2 & 2,7 \\
\hline \multicolumn{3}{|l|}{ Asupan magnesium } \\
\hline Kurang $(<300 \mathrm{mg})$ & 71 & 95,9 \\
\hline Lebih $(\geq 300 \mathrm{mg})$ & 3 & 4,1 \\
\hline \multicolumn{3}{|l|}{ Asupan lemak } \\
\hline Kurang (<30 mg) & 71 & 95,9 \\
\hline Lebih $(\geq 30 \mathrm{mg})$ & 3 & 4,1 \\
\hline
\end{tabular}

Pengaruh senam bugar lansia terhadap daya tahan jantung paru, status gizi, dan tekanan darah

Pengaruh senam bugar lansia terhadap daya tahan jantung paru. Gambar 1 menunjukkan bahwa rerata nilai daya tahan jantung paru subjek sebelum perlakuan sebesar $1,6255 \mathrm{~km}$ dan setelah perlakuan diperoleh peningkatan rerata daya tahan jantung paru subjek menjadi 1,6276 km. Hasil uji statistik daya tahan jantung paru subjek sebelum dan sesudah perlakuan dilakukan dengan wilcoxon signed ranks test seperti pada Tabel 2.

Tabel 2 menunjukkan terjadi peningkatan daya tahan jantung paru sebelum dengan setelah perlakuan 


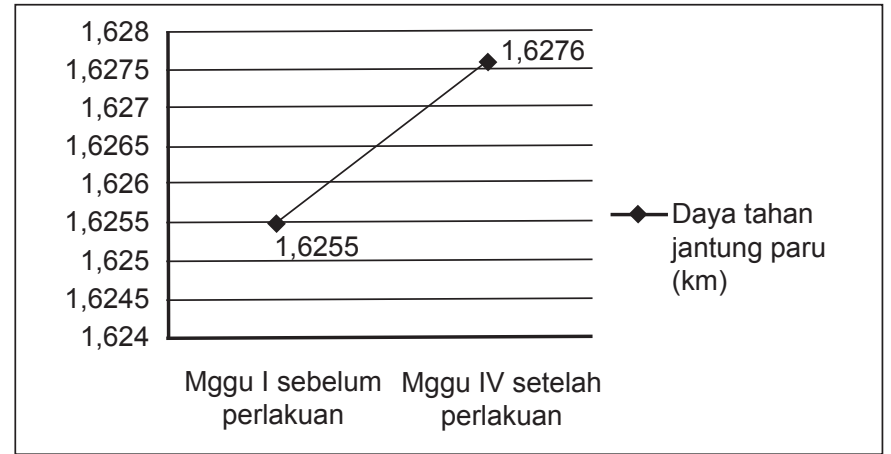

Gambar 1. Hasil rerata nilai daya tahan jantung paru subjek sebelum dan setelah perlakuan senam bugar lansia

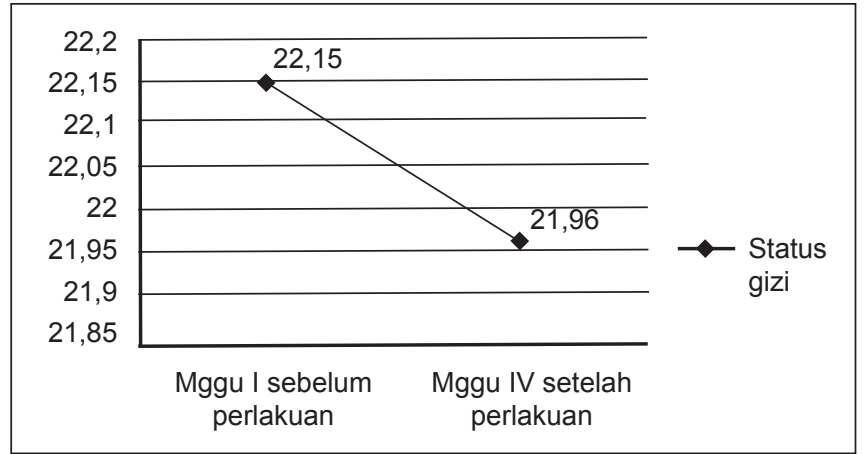

Gambar 2. Hasil rerata nilai status gizi subjek sebelum dan setelah perlakuan senam bugar lansia

Tabel 2. Hasil pengukuran daya tahan jantung paru dan status gizi sebelum dan sesudah perlakuan senam bugar lansia

\begin{tabular}{|c|c|c|c|c|c|}
\hline \multirow{2}{*}{ Aspek } & \multicolumn{3}{|c|}{ Hasil pengukuran (Rerata $\pm S D$ ) } & \multirow[b]{2}{*}{$\mathbf{p}$} & \multirow{2}{*}{ Keterangan } \\
\hline & Sebelum & Sesudah & Selisih & & \\
\hline Daya tahan jantung paru* $(\mathrm{km})$ & $1,625 \pm 0,122$ & $1,627 \pm 0,121$ & $0,002 \pm 0,004$ & 0,001 & Peningkatan \\
\hline Status gizi** $\left(\mathrm{kg} / \mathrm{m}^{2}\right)$ & $22,15 \pm 2,6$ & $21,96 \pm 2,4$ & $0,18 \pm 0,47$ & 0,002 & Status gizi \\
\hline
\end{tabular}

Keterangan:

* = wilcoxon signed ranks test

** = paired sample test

$\mathrm{SD}=$ standar deviasi

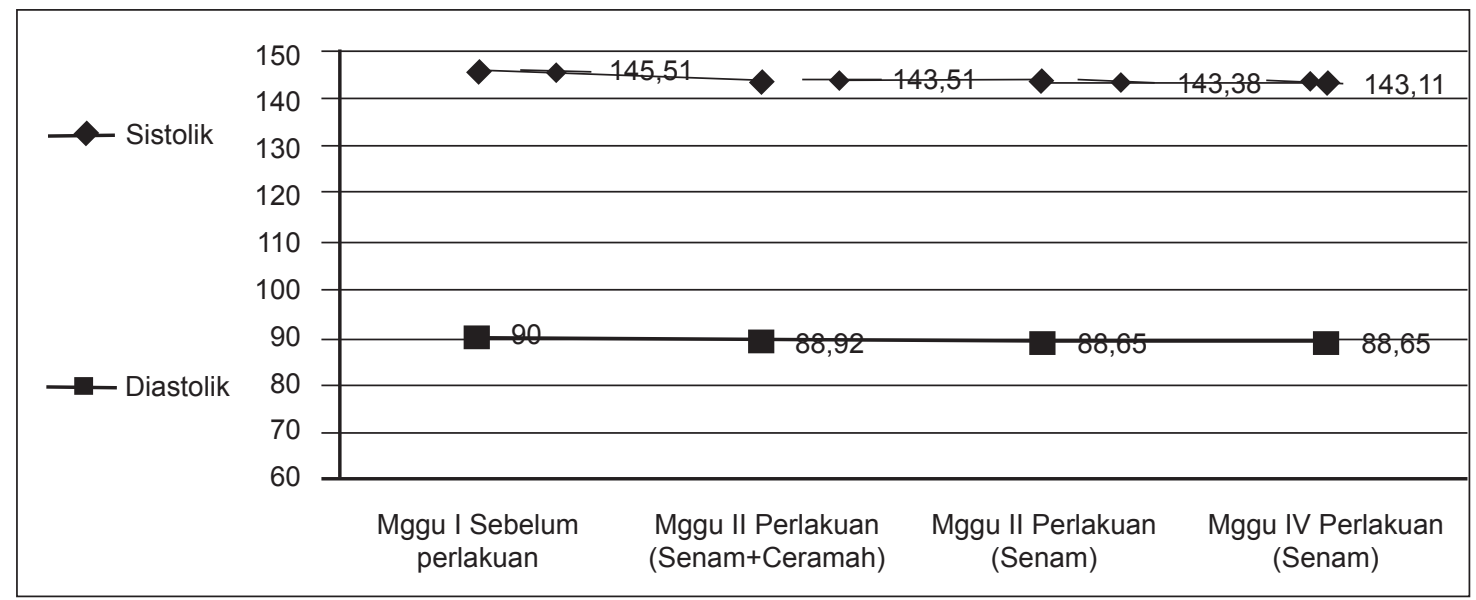

Gambar 3. Hasil rerata nilai tekanan darah subjek sebelum dan setelah perlakuan senam bugar lansia

senam bugar lansia sebesar 0,002 km dengan standar deviasi $\pm 0,004 \mathrm{~km}$. Berdasarkan hasil wilcoxon signed ranks test diperoleh nilai $p=0,001(p<0,05)$, hal ini berarti ada perbedaan bermakna daya tahan jantung paru subjek sebelum perlakuan dengan minggu keempat setelah perlakuan senam bugar lansia.

\section{Pengaruh senam bugar lansia terhadap status} gizi. Gambar 2 menunjukkan rerata nilai status gizi subjek sebelum perlakuan sebesar $22,15 \mathrm{~kg} / \mathrm{m}^{2}$ dan sesudah perlakuan senam bugar lansia menjadi $21,96 \mathrm{~kg} / \mathrm{m}^{2}$. Subjek dengan obesitas sebelum perlakuan sebanyak 11 orang $(14,87 \%)$ sedangkan tidak obesitas atau normal sebanyak 63 orang $(85,13 \%)$ dan sesudah perlakuan subjek dengan obesitas berkurang menjadi 5 orang $(6,75 \%)$ dan tidak obesitas atau normal menjadi 69 orang $(93,2 \%)$. Status gizi lansia diukur berdasarkan body mass armspan (BMA). Hasil uji statistik status gizi subjek sebelum dan sesudah perlakuan dilakukan dengan paired sample test seperti pada Tabel 2.

Tabel 2 menunjukkan bahwa status gizi sebelum dan sesudah perlakuan senam bugar lansia terjadi penurunan sebesar $0,18 \mathrm{~kg} / \mathrm{m}^{2}$ dengan standar deviasi $\pm 0,47 \mathrm{~kg} / \mathrm{m}^{2}$. Berdasarkan hasil paired sample test diperoleh nilai $\mathrm{p}=0,002$ $(p<0,05)$, hal ini berarti ada perbedaan bermakna pengukuran status gizi subjek sebelum perlakuan dengan minggu keempat setelah perlakuan senam bugar lansia.

Pengaruh senam bugar lansia terhadap tekanan darah. Gambar 3 menunjukkan rerata nilai tekanan darah subjek sebelum perlakuan adalah $145,51 / 90 \mathrm{mmHg}$, 
Tabel 3. Hasil pengukuran tekanan darah sistolik dan diastolik sebelum dan sesudah perlakuan senam bugar lansia

\begin{tabular}{lccccc}
\hline \multicolumn{1}{c}{ Aspek } & \multicolumn{2}{c}{ Hasil pengukuran (mean \pm SD) } & & \\
\cline { 2 - 6 } & Sebelum & Sesudah & Selisih & p & Keterangan \\
\hline Tekanan darah sistolik (mmHg) & & & & \\
Sebelum-minggu kedua & $145,51 \pm 4,9$ & $143,51 \pm 6,08$ & $2,0 \pm 0,83$ & 0,001 & Penurunan \\
Sebelum-minggu ketiga & $145,51 \pm 4,9$ & $143,38 \pm 5,97$ & $2,1 \pm 0,47$ & 0,001 & Penurunan \\
Sebelum-minggu keempat & $145,51 \pm 4,9$ & $143,11 \pm 5,75$ & $2,4 \pm 0,42$ & 0,001 & Penurunan \\
\hline Tekanan darah diastolik (mmHg) & & & & & Penurunan \\
Sebelum-minggu kedua & $90 \pm 0,0$ & $88,92 \pm 3,13$ & $1,08 \pm 0,36$ & 0,005 & Penurunan \\
Sebelum-minggu ketiga & $90 \pm 0,0$ & $88,65 \pm 3,44$ & $1,4 \pm 0,40$ & 0,002 & Penurunan \\
Sebelum-minggu keempat & $90 \pm 0,0$ & $88,65 \pm 3,44$ & $1,4 \pm 0,40$ & 0,002 & \\
\hline
\end{tabular}

Keterangan : SD = standar deviasi

minggu kedua setelah perlakuan senam dan ceramah menurun menjadi 143,51/88,92 $\mathrm{mmHg}$, minggu ketiga setelah perlakuan senam menurun menjadi 143,38/88,65 $\mathrm{mmHg}$, dan minggu keempat dengan perlakuan senam tekanan darah menurun menjadi 143,11/88,65 $\mathrm{mmHg}$.

Pada Tabel 3 menunjukkan terjadi penurunan tekanan darah sistolik sebelum perlakuan dengan minggu kedua setelah perlakuan senam bugar lansia disertai ceramah diperoleh selisih penurunan sebesar 2,0 $\mathrm{mmHg}$ dengan standar deviasi $\pm 0,83 \mathrm{mmHg}$, hasil wilcoxon signed ranks test diperoleh nilai sistolik $p=0,001$ $(p<0,05)$. Sebelum perlakuan dan minggu ketiga setelah perlakuan senam bugar lansia diperoleh selisih penurunan sebesar 2,1 $\mathrm{mmHg}$ dengan standar deviasi $\pm 0,47 \mathrm{mmHg}$, hasil wilcoxon signed ranks test diperoleh nilai $p=0,001$ $(p<0,05)$. Sebelum perlakuan dan minggu keempat setelah perlakuan senam bugar lansia diperoleh selisih sebesar 2,4 mmHg dengan standar deviasi $\pm 0,42 \mathrm{mmHg}$, hasil wilcoxon signed ranks test diperoleh nilai $p=0,001$ $(p<0,05)$. Hal ini menunjukkan ada perbedaan bermakna pengukuran tekanan darah sistolik subjek sebelum perlakuan dengan minggu kedua, ketiga, dan keempat setelah perlakuan senam bugar lansia.

Tabel 3 juga menunjukkan bahwa terjadi penurunan tekanan darah diastolik sebelum perlakuan dengan minggu kedua setelah perlakuan senam disertai ceramah, diperoleh selisih penurunan sebesar 1,08 $\mathrm{mmHg}$ dengan standar deviasi $\pm 0,36 \mathrm{mmHg}$, hasil wilcoxon signed ranks test diperoleh nilai diastolik $p=0,005(p<0,05)$. Sebelum perlakuan dan minggu ketiga setelah perlakuan senam diperoleh selisih penurunan sebesar 1,4 $\mathrm{mmHg}$ dengan standar deviasi $\pm 0,40 \mathrm{mmHg}$, hasil wilcoxon signed ranks test diperoleh nilai diastolik $p=0,002(p<0,05)$. Sebelum perlakuan dan minggu keempat setelah perlakuan senam diperoleh selisih penurunan sebesar 1,4 mmHg dengan standar deviasi $\pm 0,40 \mathrm{mmHg}$, hasil wilcoxon signed ranks test diperoleh nilai diastolik $p=0,002(p<0,05)$. Hal ini menunjukkan ada perbedaan bermakna pengukuran tekanan darah diastolik subjek sebelum perlakuan senam bugar lansia dengan minggu kedua, ketiga, dan keempat setelah perlakuan senam bugar lansia.

\section{Distribusi beberapa variabel lain berdasarkan penurunan tekanan darah}

Untuk mengetahui variabel lain yang berhubungan dengan penurunan tekanan darah lanjut usia hipertensi di Posyandu Kecamatan Pahandut Kota Palangka Raya dilakukan analisis bivariat dan multivariat. Tabel 4 menunjukkan tidak ada hubungan yang bermakna $(p>0,05)$ antara variabel lain dengan penurunan tekanan darah sistolik lanjut usia hipertensi. Analisis bivariat diperoleh nilai $p$ lebih dari 0,25 sehingga tidak dapat diteruskan dengan uji multivariat.

Tabel 5 menunjukkan bahwa variabel yang berhubungan secara bermakna $(p<0,05)$ dengan penurunan tekanan darah diastolik lanjut usia hipertensi di posyandu Kecamatan Pahandut adalah asupan kalsium.

Tabel 4. Hasil uji Chi Square $\left(\chi^{2}\right)$ variabel lain berdasarkan penurunan tekanan darah sistolik

\begin{tabular}{|c|c|c|c|c|c|c|}
\hline \multirow{3}{*}{ Variabel } & \multicolumn{4}{|c|}{$\begin{array}{c}\text { Penurunan tekanan } \\
\text { darah sistolik }\end{array}$} & \multirow{3}{*}{$\chi^{2}$} & \multirow{3}{*}{$\mathbf{p}$} \\
\hline & \multicolumn{2}{|c|}{ Turun } & \multicolumn{2}{|c|}{ Tetap } & & \\
\hline & $\mathbf{n}$ & $\%$ & $\mathbf{n}$ & $\%$ & & \\
\hline \multicolumn{7}{|l|}{ Status merokok } \\
\hline Tidak merokok & 11 & 100 & 57 & 90,48 & & \\
\hline Merokok & 0 & 0 & 6 & 9,52 & 1,14 & 0,286 \\
\hline Total & 11 & 100 & 63 & 100 & & \\
\hline \multicolumn{7}{|l|}{ Asupan natrium } \\
\hline Kurang & 48 & 94,1 & 8 & 34,8 & & \\
\hline Lebih & 3 & 5,9 & 15 & 65,2 & 0,061 & 0,805 \\
\hline Total & 51 & 100 & 23 & 100 & & \\
\hline \multicolumn{7}{|l|}{ Asupan kalium } \\
\hline Kurang & 58 & 98,3 & 10 & 66,7 & & \\
\hline Lebih & 1 & 1,7 & 5 & 33,3 & 0,017 & 0,897 \\
\hline Total & 59 & 100 & 15 & 100 & & \\
\hline \multicolumn{7}{|l|}{ Asupan kalsium } \\
\hline Kurang & 11 & 100 & 62 & 98,41 & & \\
\hline Lebih & 0 & 0 & 1 & 1,59 & 0,177 & 0,674 \\
\hline Total & 11 & 100 & 63 & 100 & & \\
\hline \multicolumn{7}{|l|}{ Asupan magnesium } \\
\hline Kurang & 10 & 90,9 & 60 & 95,23 & & \\
\hline Lebih & 1 & 9,1 & 3 & 4,76 & 0,343 & 0,558 \\
\hline Total & 11 & 100 & 63 & 100 & & \\
\hline \multicolumn{7}{|l|}{ Asupan lemak } \\
\hline Kurang & 10 & 90,9 & 55 & 87,3 & & \\
\hline Lebih & 1 & 9,1 & 8 & 12,7 & 0,114 & 0,736 \\
\hline Total & 11 & 100 & 63 & 100 & & \\
\hline
\end{tabular}


Tabel 5. Hasil uji Chi Square $\left(\chi^{2}\right)$ variabel lain berdasarkan penurunan tekanan darah diastolik

\begin{tabular}{|c|c|c|c|c|c|c|}
\hline \multirow{3}{*}{ Variabel } & \multicolumn{4}{|c|}{$\begin{array}{l}\text { Penurunan tekanan } \\
\text { darah diastolik }\end{array}$} & \multirow{3}{*}{$\chi^{2}$} & \multirow{3}{*}{$\mathbf{p}$} \\
\hline & \multicolumn{2}{|c|}{ Turun } & \multicolumn{2}{|c|}{ Tetap } & & \\
\hline & $\mathbf{n}$ & $\%$ & $\mathbf{n}$ & $\%$ & & \\
\hline \multicolumn{7}{|l|}{ Status merokok } \\
\hline Tidak merokok & 9 & 90 & 59 & 92,2 & & \\
\hline Merokok & 1 & 10 & 5 & 7,8 & 0,056 & 0,814 \\
\hline Total & 10 & 100 & 64 & 100 & & \\
\hline \multicolumn{7}{|l|}{ Asupan natrium } \\
\hline Kurang & 48 & 96 & 8 & 33,3 & & \\
\hline Lebih & 2 & 4 & 16 & 66,7 & 0,117 & 0,732 \\
\hline Total & 50 & 100 & 24 & 100 & & \\
\hline \multicolumn{7}{|l|}{ Asupan kalium } \\
\hline Kurang & 8 & 80 & 60 & 93,75 & & \\
\hline Lebih & 2 & 20 & 4 & 6,25 & 2,195 & 0,138 \\
\hline Total & 10 & 100 & 64 & 100 & & \\
\hline \multicolumn{7}{|l|}{ Asupan kalsium } \\
\hline Kurang & 9 & 90 & 64 & 100 & & \\
\hline Lebih & 1 & 10 & 0 & 0 & 6,48 & 0,011 \\
\hline Total & 10 & 100 & 64 & 100 & & \\
\hline \multicolumn{7}{|l|}{ Asupan magnesium } \\
\hline Kurang & 10 & 100 & 60 & 93,75 & & \\
\hline Lebih & 0 & 0 & 4 & 6,25 & 0,66 & 0,416 \\
\hline Total & 10 & 100 & 64 & 100 & & \\
\hline \multicolumn{7}{|l|}{ Asupan lemak } \\
\hline Kurang & 9 & 90 & 56 & 87,5 & & \\
\hline Lebih & 1 & 10 & 8 & 12,5 & 0,51 & 0,822 \\
\hline Total & 10 & 100 & 64 & 100 & & \\
\hline
\end{tabular}

\section{Analisis multivariat}

Analisis multivariat yang digunakan adalah regresi logistik ganda untuk menemukan model regresi yang paling sesuai dalam memprediksikan variabel independen yang berhubungan dengan variabel dependen. Semua variabel yang mempunyai nilai $p$ kurang dari 0,25 pada hasil analisis bivariat dimasukkan ke dalam model regresi logistik ganda. Namun hasil analisis bivariat tidak dapat dilanjutkan ke analisis multivariat karena hanya satu variabel yang memenuhi syarat yaitu asupan kalsium.

\section{BAHASAN}

\section{Karakteristik subjek penelitian}

Subjek penelitian adalah penderita hipertensi dengan tekanan darah sistolik 140-159 mmHg dan tekanan darah diastolik 90-99 mmHg. Berdasarkan jenis kelamin, proporsi hipertensi lebih besar pada perempuan $(78,4 \%)$ dibandingkan dengan laki-laki $(21,6 \%)$. Hasil penelitian ini sesuai dengan penelitian sebelumnya yang dilakukan di Istambul, menemukan bahwa proporsi hipertensi lebih besar pada perempuan sebesar $85,1 \%$ dibandingkan dengan lakilaki sebesar 14,9\% (17). Hasil penelitian yang dilakukan di Swedia juga menemukan proporsi hipertensi lebih besar pada perempuan $(56,4 \%)$ dibandingkan dengan laki-laki $(43,6 \%)$. Berbeda dengan penelitian yang dilakukan di Polandia yang menemukan bahwa proporsi hipertensi lebih banyak pada laki-laki dibandingkan perempuan (18), tetapi secara umum proporsi hipertensi lebih tinggi pada perempuan dibandingkan laki-laki karena dipengaruhi oleh faktor hormonal (penurunan kadar estrogen pada wanita menopause), paritas, dan pengaruh pemakaian alat kontrasepsi.

Survei kesehatan di 5 kecamatan pada penduduk Kota Yogyakarta dengan rancangan cross sectional juga menemukan penderita hipertensi lebih besar $(55,8 \%)$ pada kelompok umur 55-65 tahun dibandingkan dengan kelompok umur di bawah 54 tahun (40,9\%). Prevalensi hipertensi pada populasi berumur di atas 45 tahun akan meningkat terutama pada wanita. Peningkatan penderita hipertensi sejalan dengan bertambahnya umur. Kecenderungan naiknya tekanan darah pada lanjut usia mungkin ada hubungannya dengan menurunnya kemampuan mengekskresi garam, meningkatnya aktivitas saraf simpatik, hilangnya distensibilitas aorta dan pembuluh darah besar serta faktor lainnya. Pada usia tua diperlukan volume darah lebih banyak untuk memompakan sejumlah darah ke otak, dan alat vital lainnya seperti jantung, paru-paru, dan hati, di samping pada usia tua pembuluh darah sudah mulai mengeras dan dinding pembuluh darah sudah menebal (19).

\section{Pengaruh senam bugar lansia terhadap daya tahan jantung paru}

Berdasarkan hasil wilcoxon signed ranks test diperoleh nilai $p=0,001(p<0,05)$, ini berarti ada perbedaan bermakna pengukuran daya tahan jantung paru subjek sebelum perlakuan dengan minggu keempat setelah perlakuan senam bugar lansia. Kegiatan fisik dan olahraga secara teratur bermanfaat untuk meningkatkan kebugaran, mencegah kelebihan berat badan, meningkatkan fungsi jantung, paru dan otot, meningkatkan suplai darah ke hati, membantu mempertahankan kekuatan otot dan kelenturan sendi serta memperlambat proses penuaan (5). Kelebihan energi dalam tubuh akan disimpan dalam bentuk lemak akibatnya berat badan dan Indeks Massa Tubuh (IMT) akan meningkat. Jumlah lemak yang berlebihan dalam tubuh dapat menghambat kemampuan tubuh untuk melakukan aktivitas, demikian juga jika asupan lemak kurang akan mempengaruhi aktivitas fisik dan kebugaran jasmani (20).

Hasil penelitian di Kota Kupang (21) menyatakan bahwa berdasarkan hasil analisis korelasi terdapat hubungan yang bermakna antara activities of daily living $(A D L)$ atau aktivitas hidup sehari-hari dengan tingkat kebugaran lansia $(p<0,001)$. Hubungan antara ADL dengan tingkat kebugaran menunjukkan hubungan yang sangat kuat $(r=0,800)$ dan berpola positif artinya makin mandiri lanjut usia, makin tinggi tingkat kebugarannya. Nilai $R^{2}=0,64$ artinya variabel $A D L$ dapat menjelaskan variabel kebugaran sebesar $64 \%$. Nilai koefisien regresi menunjukkan hubungan positif, artinya setiap kali terjadi peningkatan 1 skor ADL akan meningkatkan kebugaran lansia sebesar 8,014. ADL tidak hanya 
berhubungan dengan kemampuan perawatan diri, tetapi juga berhubungan dengan kesehatan fisik, mental, dan kehidupan sosial.

Hal ini menunjukkan bahwa penurunan kebugaran pada lanjut usia dapat dicegah dengan berolahraga yang berintensitas ringan, berdurasi harus mencapai 45-60 menit, dan frekuensinya tiga kali seminggu (21). Seseorang melakukan latihan atau senam yang berkaitan dengan kesehatan akan mempengaruhi perkembangan kebugaran jasmaninya. Untuk mencapai kebugaran yang memadai, frekuensi senam sebaiknya 3-4 kali/minggu dengan selang hari istirahat. Senam yang tidak teratur, kadang-kadang senam, dan diselingi masa istirahat yang lama, sama buruknya dengan tidak senam (2).

\section{Pengaruh senam bugar lansia terhadap status gizi}

Berdasarkan hasil paired sample test diperoleh nilai $p=0,002(p<0,05)$, ini berarti ada perbedaan bermakna pengukuran status gizi subjek sebelum dan setelah perlakuan senam bugar lansia. Hasil penelitian ini didukung oleh hasil penelitian Permaesih et al (22) yang menyatakan bahwa terdapat hubungan yang bermakna antara status gizi dengan kebugaran jasmani, hubungan nyata yang bersifat negatif sehingga dapat menurunkan kebugaran jasmani. Status gizi mempunyai korelasi yang tinggi dengan jumlah timbunan lemak dalam tubuh sehingga akan mengakibatkan penurunan tingkat kebugaran jasmani. Berbeda dengan hasil penelitian di Kupang yang menyatakan bahwa hubungan antara status gizi dengan tingkat kebugaran menunjukkan hubungan yang lemah $(r=0,126)$ dan berpola positif, artinya semakin normal status gizi lanjut usia semakin baik tingkat kebugarannya. Hasil uji statistik diperoleh tidak ada hubungan yang bermakna antara status gizi dengan tingkat kebugaran lansia $(p=0,384)(21)$.

\section{Pengaruh senam bugar lansia terhadap tekanan darah}

Berdasarkan hasil wilcoxon signed ranks test tekanan darah sistolik menunjukkan perbedaan yang bermakna pada minggu kedua, ketiga, dan keempat dengan nilai $p=0,001(p<0,05)$. Sedangkan tekanan darah diastolik menunjukkan perbedaan yang bermakna pada minggu kedua $p=0,005(p<0,05)$, minggu ketiga, dan keempat dengan nilai $p=0,002(p<0,05)$.

Hasil penelitian ini sesuai dengan hasil penelitian yang dilakukan di Amerika Serikat pada orang laki-laki hipertensi berumur antara 35-76 tahun dengan perlakuan yang diamati selama 32 minggu. Perlakuan yang diberikan yaitu dengan terapi obat antihipertensi dan olahraga pada 23 pasien kelompok pertama, sedangkan 23 pasien pada kelompok kedua hanya diberi perlakuan terapi obat antihipertensi saja. Penelitian ini menunjukkan perbedaan yang bermakna $(p<0,05)$ terhadap penurunan kedua tekanan darah yaitu sistolik sebesar $6 \mathrm{mmHg}$ dan diastolik sebesar $4 \mathrm{mmHg}$.
Hasil meta-analysis uji klinis pada 54 penderita hipertensi dan normotensive juga menunjukkan perbedaan yang bermakna $(p<0,05)$ dengan penurunan tekanan darah sistolik sebesar 3,8 $\mathrm{mmHg}$ dan diastolik sebesar 2,6 mm (23).

Menurut hasil penelitian yang dilakukan di Amerika Serikat, pengaruh olahraga dalam menurunkan tekanan darah berhubungan dengan penurunan tahanan perifer. Penurunan tahanan perifer dapat dijelaskan dari dua mekanisme yaitu terjadinya perubahan pada aktivitas sistem saraf simpatik dan respon vaskular setelah berolahrga. Pertama, secara neurohumoral menurunnya aktivitas sistem saraf simpatik pada pembuluh darah perifer sebagai petunjuk terjadi penurunan tekanan darah. Kedua, respon vaskular mempunyai peranan penting pada penurunan tekanan darah setelah berolahraga. Olahraga diduga dapat mengubah respon vasokonstriktor (kontraksi pembuluh darah) kuat menjadi vasodilator (mengurangi vasokontriksi atau tekanan pada pembuluh darah) dan meningkatnya produksi nitrogen oksida (NO). Olahraga dapat menunjukkan terjadinya produksi nitrogen oksida dan memperbaiki vasodilator pada orang yang sehat (24).

Hasil penelitian di Amerika Serikat melaporkan bahwa aktivitas fisik menyebabkan penurunan tekanan darah pada orang tua yang menderita hipertensi berhubungan dengan penurunan rata-rata hypothalamic norepineprine. Penurunan hypothalamic norepineprine sebagai reaksi menurunnya aktivitas sistem saraf simpatik dan meningkatnya fungsi sistem kardiovaskular (25).

Walaupun program perlakuan senam bugar lansia yang diberikan hanya mampu menurunkan tekanan darah sistolik sebesar 2,4 $\mathrm{mmHg}$ dan tekanan darah diastolik sebesar 1,4 mmHg (Tabel 3), relatif sedikit dari pandangan klinis tetapi sangat besar pengaruhnya pada populasi orang dewasa tua. Peningkatan tekanan darah sistolik dan mekanisme sedikit lebih penting dalam menentukan faktor risiko penyakit daripada tekanan darah diastolik terutama pada usia tua dengan bertambahnya umur (26).

Pada umur di atas 60 tahun, rata-rata tekanan darah diastolik cenderung turun tetapi tekanan darah sistolik akan terus meningkat (27), hal ini menyebabkan tingginya pulse pressure sehingga meningkatkan resiko penyakit iskemik miokard, penyakit jantung, dan stroke (28). Hasil penelitian di Amerika Serikat menyebutkan bahwa penurunan tekanan darah sistolik dan diastolik $2 \mathrm{mmHg}$ secara bertahap dapat menurunkan risiko penyakit stroke $(17 \%)$ dan jantung koroner (9\%) (24). Hasil penelitian uji klinis menunjukkan penurunan prevalensi penyakit kardiovaskular berhubungan dengan treatment yang dilakukan terhadap tekanan darah sistolik (26).

Hasil penelitian ini menunjukkan bahwa senam bugar lansia secara teratur dan terukur dapat menurunkan tekanan darah dan menjadi tolok ukur tingkat keberhasilan penatalaksanaan penderita hipertensi di masyarakat. Pengaruh positif latihan senam terhadap penurunan 
tekanan darah belum diketahui secara jelas, namun diduga melalui beberapa mekanisme yaitu menurunnya tahanan perifer vaskular, menurunnya kadar serum katekholamin, dan penurunan aktivitas plasma renin.

\section{KESIMPULAN DAN SARAN}

Perlakuan senam bugar lansia berpengaruh terhadap peningkatan daya tahan jantung paru, penurunan status gizi, dan penurunan tekanan darah. Berdasarkan hasil penelitian maka disarankan program senam bugar lansia terus dilaksanakan serta perlu diberikan penyuluhan dan konsultasi secara berkesinambungan, agar tercapai tingkat kebugaran lansia. Saran untuk penelitian selanjutnya, diharapkan melihat penurunan tekanan darah dengan pengamatan lebih lama, metodologi penelitian eksperimen dengan program intervensi kombinasi antara aktivitas fisik, diit, dan obat antihipertensi.

\section{UCAPAN TERIMA KASIH}

Peneliti mengucapkan terima kasih kepada Walikota Palangka Raya, Kepala Puskesmas Pahandut dan Panarung, enumerator, dan semua responden yang terlibat dalam penelitian ini.

\section{RUJUKAN}

1. Notoatmodjo S. Ilmu kesehatan masyarakat ilmu dan seni. Jakarta: Rineka Cipta; 2007.

2. Bustaman A. Pembinaan kesegaran jasmani untuk lanjut usia. Dalam Harsuki. Perkembangan olahraga terkini. Jakarta: Rajagrafindo Persada; 2005.

3. Sari NK. Gangguan nutrisi pada usia lanjut. Dalam: Sudoyo AW, Setiyohadi B, Alwi I, Simadibrata M, Setiati S, editor. Buku ajar ilmu penyakit dalam, Jilid III Edisi IV. Jakarta: Pusat Penerbitan IImu Penyakit Dalam FaKultas Kedokteran Universitas Indonesia; 2007.

4. Riyadi A, Wiyono P, Budiningsari RD. Asupan gizi dan status gizi sebagai faktor risiko hipertensi esensial pada lansia di Puskesmas Curup dan Perumnas Kabupaten Rejang Lebong Provinsi Bengkulu. Jurnal Gizi Klinik Indonesia 2007; 4(1): 43-51.

5. Wibowo H. Lanjut usia dan olahraga. Dalam Harsuki. Perkembangan olahraga terkini. Jakarta: Rajagrafindo Persada; 2005.

6. Suwarni, Asdie HAH, Astuti H. Konseling gizi dan pengaruhnya terhadap asupan gizi dan tekanan darah pada pasien hipertensi rawat jalan di RSUD Provinsi Sulawesi Tenggara. Jurnal Gizi Klinik Indonesia 2009; 6(1): 21-8.

7. Yogiantoro M. Hipertensi esensial. Dalam: Sudoyo AW, Setiyohadi, B, Alwi I, Simadibrata M, Setiati S, editor. Buku ajar ilmu penyakit dalam Jilid I Edisi IV. Jakarta:
Pusat Penerbitan IImu Penyakit Dalam Fakultas Kedokteran Universitas Indonesia; 2007.

8. Dalimartha S, Purnama, BT, Sutarina N, Mahendra B, Darmawan R. Care your self hipertensi. Jakarta: Penebar Plus; 2008.

9. Ferry, Kushartanti W, Noerhadi M. Konsumsi karbohidrat dan lemak dan hubungannya dengan daya tahan jantung paru atlet sepak bola PS Semen Padang Divisi Utama PSSI Liga Bank Mandiri IX tahun 2003. Jurnal Gizi Klinik Indonesia 2009; 5(1): 16-20.

10. Lemeshow S, Hosmer Jr DW, Klar J. Adequacy of sample size in health studies. Pramono D.1997 (Alih bahasa). Yogyakarta: Gadjah Mada University Press; 1997.

11. Departemen Kesehatan RI. Pedoman umum pengelolaan posyandu. Jakarta: Depkes RI; 2006.

12. Puspitorini M. Hipertensi cara mudah mengatasi tekanan darah tinggi. Jakarta: Image Press; 2008.

13. Proboprastowo SM, Dwiriani CM. Angka kecukupan air dan elektrolit. Dalam Widyakarya Nasional Pangan dan Gizi VII. Prosiding Ketahanan Pangan dan Gizi di Era Otonomi Daerah dan Globalisasi; 2004 May 17-19; Jakarta.

14. Soekatri M, Kartono D. Angka kecukupan kalsium, fosfor, magnesium, flour. Dalam Widyakarya Nasional Pangan dan Gizi VIII. Prosiding Ketahanan Pangan dan Gizi di Era Otonomi Daerah dan Globalisasi; 2004 May 17-19; Jakarta.

15. Hardinsyah, Tambunan V. Angka kecukupan energi, protein, lemak dan serat makanan. Dalam Widyakarya Nasional Pangan dan Gizi VIII. Prosiding Ketahanan Pangan dan Gizi di Era Otonomi Daerah dan Globalisasi; 2004 May 17-19; Jakarta.

16. Suhardo M. Senam bugar lansia AWARA(SBL-AWARA) $2^{\text {nd }}$. Yogyakarta: Perwosi \& Tim Penggerak PKK Propinsi Daerah Istimewa Yogyakarta bekerja sama dengan Medika Fakultas kedokteran UGM; 2004.

17. Onal AE, Erbil S, Ozel S, Aciksari K, Turmedem Y. The prevalence of and risk factors for living in hypertension in adults living in Istambul. Blood Pressure 2004; 1 : 31-6.

18. Grzybowski A, Bellwon J, Gruchala, M, Stolarczyk L, Popaszkiewicz J, Sobiczewski W, Rynkiewicz A. Effectiveness of hypertension treatment assessed by blood pressure level achieved in primary care setting in poland. Blood Pressure 2003; 12: 232-8.

19. Cleroux J, Kouame N, Nadeau A, Coulombe D, Lacourciere Y. After effects of exercise on regional and systemic hemodinamic in hypertension. Hypertension 1982; 19(2): 183-91.

20. Jellife DB, Jellife EFP. Community nutritional assessment. Oxford: University Press; 1989.

21. Setia A, Pramantara IDP, Pangastuti R. Faktor-faktor yang mempengaruhi tingkat kebugaran lanjut usia 
penghuni Panti Budi Agung Kupang di Kota Kupang. Jurnal Gizi Klinik Indonesia 2006; 3(2): 56-65.

22. Permaesih D, Kusdinar A, Ivone MI, Dangsina M, Hendro R. Faktor-faktor yang mempengaruhi ketahanan kardiovaskuler pada pria dewasa. Buletin Penelitian Kesehatan 1999; 27(2): 231-23.

23. Kokkinons PF, Narayan P, Colleran JA, Pittaras A, Notargiacomo A, Reda D, Papademetriou V. Effect of reguler exercise on blood pressure and left ventricular hypertrophy in African-American men with severe hypertension. N Engl J Med 1995; 333(22): 1462-7.

24. Pescatello LS, Franklin BA, Fagard R, Farquhar WB, Kelly GA, Ray CA. Exercise and hypertension. Med Sci Sports Exerc 2004; 36(3): 533-53.
25. Brown MD, Dengel DR, Hogikyan RV, Supiano MA. Sympathetic activity and the heterogenous blood pressure response to exercise training in hypertensives. J Appl Physiol 2002; 92(4): 1434-42.

26. Liyod-Jones DM, Evans JC, Larson GM, O'DonnellI JC, Levy D. Differential impact of systolic and diastolic blood pressure level on JNC-VI staging. Journal Of The American Heart Association 1999; 34 : 381-5.

27. Franklin SS, Gustin W, Wong ND, Larson Mg, Weber MA, Kannel WB, Levy D. Hemodynamic patterns of age-related change in blood pressure. The Framingham Heart Study 1997; 308-15.

28. Bacon SL, Sherwood A, Hinderliter A, Blumental JA. Effects of exercise, diet and weight loss on high blood pressure. Sports Med 2004; 34(5): 307-16. 